\title{
Personality in Contemporary Western Political Thought: Emmanuel MOUNIER as a Model
}

\author{
Assistant Professor Dr ABEER SHAM MAHDI . \\ College of Political Science, University of Baghdad research field: political science: Political thought. \\ Al - JADRIYA Complex, Baghdad, Iraq
}

\begin{abstract}
Objectives: Personality emerged in a historical era in which the world, Europe and France were witnessing the end of a civilization period that stretched from the end of the Middle Ages until the early twentieth century, characterized by being capitalist composition, liberalism of the method and the bourgeoisie of values. Rather, it is also in response to the materialist and existential atheist school of Marxism, with the aim of which is the further goal of remaking the Renaissance. One of the most important intellectual currents that appeared in France during the thirties of the twentieth century in addition to existentialism and phenomenology. Personality is based on an ethical principle based on its content, respect for the human person and its absolute value. It rises above the world of political and economic institutions that are nothing but methods in the service of the person.

Results: Personality arose with the French thinker (Charles Ronovier) in the late nineteenth century, but it did not witness its true revolution except with the French philosopher (Emmanuel MOUNIER) who developed this and idea and gave it a personal nature that is in harmony with the reality and living from it

Findings: Hence the hypothesis of our research labeled (Personality in Contemporary Western Political Thought: Emmanuel Monier as a model) was launched from the fact that personality has formed an intellectual trend and came to denounce the situation that has reached man, as it presented in its intellectual forms a new vision about the nature of man and his essence. To demonstrate the research hypothesis, we raise the following questions What is meant by personality? What are its most important characteristics?

Who are the most prominent pioneers of personality? And were they able to present a new vision about man? What is the relationship of personality to Marxism and existentialism ?

In light of the questions raised in the research hypothesis, the research was divided into four topics, in addition to the introduction and conclusion

Conclusion: Emmanuel Meniere's one of the most prominent pioneers who presented a vision of the person based on the merging of what is spiritual with what is material in the human being while giving precedence to what is spiritual, stressing that personality is based on communication and human relations, because the person does not perceive himself except with others And highlighting the priority of the self over the subject and the self-existence over the total perception, personality sought to present itself as a solution to the human crisis that appears economic and spiritual depth cultural or as an alternative to the worsening crisis multidimensional in Europe and others
\end{abstract}

Keywords: Contemporary Western Political Thought Emmanuel Mounier. Personality

DOI: $10.7176 / \mathrm{EJBM} / 13-7-05$

Publication date: April $30^{\text {th }} 2021$

\section{Introduction}

The economic contradictions and crises produced by the capitalist system have led to the spread and emergence of many philosophies during the twentieth century. In the global crisis of 1929, personality emerged as a reaction to the huge economic and industrial development that prevailed in the world, the machine's control over economic production, and the sweeping of the utilitarian tendency of human relations The relations of individuals among them became governed by interests and benefits, and this was reflected negatively on the individual's personality by emptying his spiritual and moral energy, which is considered the real guide for his behavior and his relationships with others.

In the midst of all this, personality came to set the monument in the eye of the person, referring to the causes of this crisis in which a person lives, to a spiritual moral crisis that led to the bankruptcy of man from his values, as it is a crisis that expresses the extent of the spiritual, spiritual and moral collapse that has befallen modern man.

Hence the hypothesis of our research labeled (Personality in Contemporary Western Political Thought: Emmanuel Monier as a model) was launched from the fact that personality has formed an intellectual trend and came to denounce the situation that has reached man, as it presented in its intellectual forms a new vision about the nature of man and his essence. To demonstrate the research hypothesis, we raise the following questions

What is meant by personality? What are its most important characteristics ?

Who are the most prominent pioneers of personality? And were they able to present a new vision about 
man?

What is the relationship of personality to Marxism and existentialism ?

In light of the questions raised in the research hypothesis, the research was divided into four topics, in addition to the introduction and conclusion

In the first topic we dealt with: a theoretical framework for the concept of personality and convergent concepts, the second topic was devoted to examining the intellectual rooting of personality in modern Western political thought. As for the third topic, it was organized under the title: Personality and its relation to other intellectual currents: Marxism and existentialism, and the fourth topic was devoted to a discussion: Personality in the thought of Emmanuel Monnet

2...the concept of personality is a language and idiom: personality defines a language as: taken from the word (person), and this word defines it

(Ibn Manzur) by saying: (The person has everybody that has height and appearance and is intended to prove the self) and from it the saying that says: (A person is the person himself With its apparent and elevated body (Deats, P.; Robb, C. (1986)..

As for the glossary of inclusive meanings, personality was defined as: a philosophical theory whose effect: personality is at the top of the categories and it is the one that rationalizes the world as an absolute value( Lawler, R. D. (1982). The Christian ), in addition to that it was defined as: an ethical and social theory that is based On the absolute value of a person, to which everything is given (( Crosby, John (2003). Personalist Papers )).

As for personality in the English language, it is known as the term (personalism), which is an ancient philosophical movement concerned with the study of the individual personality as the main influencing factor in the environment surrounding the individual, in addition to the fact that personality is defined as: the realistic view towards the things granted by the character of the character, i.e. deals with it in terms of its real existence (( Miles, R. (2010). Georgia Harkness )).(

As a convention, the term philosophical personality was used for the first time by the German philosopher and scientist (Schleiermacher) in the year (1799), which pointed to the pivotal role of personality in philosophy, and it is the direct influence on the construction of philosophical thought, and relied on supporting his opinion on Latin philosophical studies on the idea of abstract personality, Which refers to individuals who are in a certain social sphere that directly controls the nature of their personalities (Burrow, R. (1999). Personalism: a Critical Introduction. ), as it was defined as: a philosophical doctrine that calls for freedom, and rejects all restrictions that nullify the freedom and creativity of the person, and also calls that the individual must be integrated with society without He loses himself It was also known as: A philosophical system centered on the person (Deweer, D. (2013). The political theory of personalism: ).

Through the foregoing, we conclude that there is no universal definition that prevents personality, as it was divided between movement, doctrine and philosophy, except for most of these definitions, which unanimously emphasize that personality emphasizes the individual by its absolute value and the nominal element of existence and presenting its interest in an interest community.

\section{3...characteristics of personality}

The characteristics of personality can be summarized in the following (Bengtsson, Jan Olof, 2006, The Worldview of Personalism))

Insist that there is a set of differences between the various personalities that distinguish each character from other characters

the inability to personalize the abbreviation, that is, each character is a complete and integral component that cannot be divided or deal with only a specific case of it

Every person has a distinct personality, and does not necessarily resemble any other personalities, except in some common features that relate to family or community customs.

Focuses on relationality, that is, the links that link a person and his environment, whether it is a bond of religion, race, language, or other links.

\section{3..1 personality and related concepts}

Individualism: Individualism is defined in the philosophical glossary of Jamil Saliba as:

"The doctrine of the one who sees that the purpose of society is to take care of the individual's interest and allow him to manage his own affairs." (Bowne, Borden Parker, 1908, Personalism ), and individualism in ethics and politics is called to say: Of the value of the institutions surrounding it, because the individual is the goal for which the state existed and individuality means: (individual independence in the relationship with the state or with any other structure or in other words, dissociation or liberation from the power of the group

Individuality is synonymous with personality or personality, but the modernists differentiate between them. The personality is the sum of the qualities that make the individual fit for life in a known spiritual society. As for 
individuality, it is the sum of the characteristics that distinguish the individual from the members of his type or society. In fact, everyone in this work is an individual, and not everyone is a person (Brightman, Edgar S. (ed.), 1943. Personalism in Theology ). Individualism is governed by many external factors, while personality is based on the individual's ability to focus voluntarily

Will is the basis of each individual and it is a factor of self-realization due to its superior potential, because by will, the individual can be distinguished from the group and by this The will becomes the command to give oneself orders

There are two different patterns of will: the product of individualism, the realization of which leads to different results. The will of power at Nietzsche leads to the rule of the powerful who do not accept equality and the participation of others, but resort to uniqueness in their liveswhile the general will of Rousseau, which is The product of individualism is based on equality and aims to achieve the public interest, which is different from the will of all, which is the sum of partial wills based on the private interest (Flewelling, Ralph Tyler and Rudolf Eucken, 1915, Personalism ).

Accordingly, personalism calls for freedom and rejects all restrictions that nullify the freedom and creativity of the person, but it sees in individualism that it is excess in the individual, especially as it calls for isolation from society, unlike personality, it calls for freedom, it calls the individual to be integrated with society without losing same

Subjectivity: expresses a philosophical tendency based on the return of every realistic value judgment to conscious individual actions or conditions, and subjectivity is a philosophical doctrine indicating that knowledge is subjective and there is no objective truth outside of the same person, and subjective is not free from ambiguity and ambiguity and is said about it In general it is: a philosophy that aims to return everything to the self and presenting oneself to the objective, i.e. giving the self a priority over the subject and returning everything to it in art, literature and philosophy and subjectivity in this sense coincides with idealistic trends in Western philosophy that return all aspects of activity Human to self, and thus self was the intellectual basis for scientific tendency Or collective self-negation of ideal idealism from Plato to Hegel (Knudson, Albert Cornelius, 1927, The Philosophy of Personalism ). So subjectivity is the main driver of individual personality, and it is classified as a major and important part of each person's personality.

\section{3..2.. the intellectual rooting of personality in modern western political thought}

Personality emerged in the twentieth century and spread in the French and American philosophies, as it came to restore to the person its value and dignity and prove its existence as a being that has the characteristics of the rational and wise being, but that does not prevent saying: that the first attributes of personality are due to ancient Greek thought, as we find it at (Enaxagoras 500-428q. M), who is considered one of the most important philosophers who focused on the mind as a basis for existence, as he defined the mind as: (the most accurate and clear things) and as he said about it is not mixed, and that it does not contain any mixing of anything besides itself, as if it was mixed with something Another that, when mixed, is able to do with the same ability as it does with pure

As for (Socrates), who took the slogan of him (Know yourself by yourself), he cared about looking at the human being, so that he turned from looking at the astronomy and the elements to the soul, as he acknowledged that the first and true knowledge is the science itself, and that the knowledge of the soul is only accomplished through its awareness of itself, as philosophy has limited itself to The circle of ethics as the most important thing that matters to man and revolves around what a person is (Ibrahim Madkour, The Philosophical Lexicon ).

We also see the signs of personality in (Plato's) thinking, as his view of man was similar to the view of his teacher (Socrates) that man is the most important being, so we find Plato's research on man in matters of individual and also as a social person, as we find from the human values that he advocates Plato has equality between men and women, as she has the right to be appointed to jobs just like men, and also to have a woman with an education of no less than the amount enjoyed by men (Personality, 06/30/2018: https://mawdoo3.com ).

Thus, the Platonic thought contributed to building knowledge and tried hard to create a person and make himself a thinker through Methods of education adopted in his academy As for the stoic school, it has been expressed that the individual does not belong only to himself, but to family, friends, people, and finally to the whole of humanity (Hassan Kahlawi, Individualism in Contemporary Philosophical Thought ).(

In the context of Roman thought, the roots of personality can be found at Cicero, who used it to refer to three different meanings, all close to the theatrical environment, such as: the mask - the masked actor - the person who represents individual distinction (tape Marwa and Sassi Iman, The Islamic Personality ).

If we find the roots of personality, we can find the Christian belief, as Christianity sanctified man and placed him in a distinctive position, considering that a person, whatever his sex, was created in the image of God Almighty, as it came in the Bible: "So God created man in His image in His image, God created him male and female He created them. In the interpretation of this, some jurists say that man is the living, moving image of the God who is the absolute on the surface of the earth. Moreover, according to this doctrine God has blessed man as 
he came in the gospel:“ Male and female He created and blessed him and called his name Adam the day of creation. (Jamil Saliba, The Philosophical Dictionary) Accordingly, the human being in the Christian faith is the image of God, the Lord of the universe, and this is what is so painful He is distinguished from the rest of the creatures, whether in terms of composition, or in terms of degree or status that he is supposed to enjoy, because he is a blessed creature with a significant and high value, and therefore the inevitable result of this doctrine is the sanctification of his life in general, regardless of his gender, color, or race. From this standpoint, Christianity prohibited bloodshed and killing the human soul, just as the values and ideals established by Christianity constituted a real revolution in a society whose relations were based on strength and class distinction. Perhaps the most important of these values is love and brotherhood among all human beings and the call for equality and justice

between the sexes by On the other hand, I confirmed the Christian On the freedom represented by freedom of belief and freedom in behaviors, as far as religious freedom is concerned, it is that relationship that binds a person to his Lord and it is a relationship that is governed by conscience and linked to the heart from within, because God wants the heart of man to be a pure and obedient heart, because every action that comes through compulsion is not a reward He has absolutely nothing in this religion, but as for freedom in behaviors, it must be restricted because man cannot claim freedom while infringing on others 'freedoms or their rights, as freedom in Christianity is related to discipline, God's commandments, law, and even public order (Abdul Ridha Al-Taan, Amer Hassan Fayad )

The concept of the person has evolved in the modern era philosophically with (Descartes), which linked the person to the self by saying: (I think then I am), so he went to emphasize the importance of thought in building the personality and understanding its reality, so thought is the characteristic of a person with the human self and it is only attached to it and it is the condition the necessary For existence, then, the basis of a person's identity is thinking that is appropriate for the presence of the self in front of itself and its direct awareness of all the actions that result from it, which remain in spite of their number one and constant (Murad Wahba, The Philosophical Lexicon. )

Immanuel Kant) goes on to emphasize the importance of a person as a subject of a practical moral mind that treats others not as means through which he achieves his own purposes but rather as ends in itself so that a person is distinguished within the nature system from the rest of other beings by having his understanding, and he has been able to draw for himself the goals and objectives conditional on the call of moral duty, He can take from things a means that he uses to achieve his purposes, but he does not have the right to treat people as a selfbeneficial means, because a person or a human self is an end in itself and not a means to achieve the purposes of others and this gives him absolute internal value and earns him self-esteem and thus has the dignity of a Man (Sally Mohsen Latif, The Art Philosophy ).

Also, the human being is not just a rational being, but rather a moral person, as looking at the human being as part of nature and as a rational animal can make him an object that is not distinguished from nature's things, and therefore it can be considered a means (tool) to achieve the goals of others, while the philosophy ( The moral calls us to look at the human being as an end in itself as it is not something (a tool and a subject) and from there it cannot be treated as a means, and here he distinguished (was) between the (natural) things the source of tendencies and needs have only a conditional value that determines its value is the results It is intended, not value itself (because it is only a means) and between people as rational beings Rosette, and free are not used as a means but as ends in themselves Taataan André Laland, Laland's Philosophical Encyclopedia(

Through the foregoing, we find that there are initial ideas about the person and the human being that formed the first seeds to form an intellectual trend that is concerned with man and researches in his world.

\section{3..3..Personality and its relation to other intellectual trends: Marxism and existentialism}

The first requirement: Personality and its relationship to Marxism

The nineteenth century in Europe witnessed a group of Western political intellectual currents until the right of the century of the emergence of ideologies. Marxism is one of the most prominent of these intellectual currents.

Marxism is a political and theoretical practice based on Karl Marx's intellectual works Marxism is a social, economic and political system, that is, before it is a dialectical and philosophical movement, it is a politicopolemical movement.

Marx) believes that everything in existence, even the human being himself, his thinking, and society, including all of them, is a reflection of the material to which it belongs, for matter has precedence from the idea and is the origin of its existence, and the human being does not He is considered a man of choice, but he is considered to be productive, and in this (Marx) says: that the real kingdom of freedom is work and production and not a person in terms of a person since a Marxist person feels strange even in himself because he has no freedom to choose Itself itself, but rather as a machine in the conduct and service of the society to which it belongs, Marxism is incompatible with the principle of personal freedom where by losing the choice, freedom is 
lost with it (Walter Sties, The History of Greek Philosophy ).

Marxism recognizes the importance of a person and society and makes them a dialectical unit that is inseparable and explains the emergence of personality historically, and the definition of the individual depends on the sum of social relations, and the human being is part of specific social groups that are classes, and the person's values value the intensity of his relations with other people, but personality is biased To the individual and to the elite whose value and role increase through their actions characterized by purity, dignity and pride. Moreover, personality differs from Marxism in its direction towards religion and belief. Marxism rejects religion and considers it the ideology of the capitalist system, but the A characteristic that sees religion as a driving force that makes a person conscious of morality, and since this moral awareness by virtue of his inherent nature is directed towards society, since the original ethics always deepens the awareness of the human being and guarantees it, any restraint or repression directed to the doctrine or religion leads necessarily to the suppression or curbing of free growth The automaticity of moral responsibility (Ghanem Muhammad Salih, the old and mediating political thought ).

Despite the agreement of personalism and Marxism that philosophy must change the world and that human society must and must be renewed and rebuilt, it, unlike Marxism, did not provide a complete and accurate intellectual program for action and practice, personalism emphasizes the need for a person to establish and establish a program of work based on concrete positions Always evolving and dependent on it (Pratrind Russell, Wisdom of the West: a historical presentation ).

Thus, personalism is built on the basis of personal freedom, it does not support Marxism and its concept of freedom, because Marxism has denied the individual person its active will, and despite attempts to portray Marxism as a philosophy defending the human being, it did not offer anything to the human being as much as it was a reason for his long-term misery

Where his freedom, dignity and the most dangerous confiscated his faith, because Marxists considered that the crisis is a crisis of economy and institutions, but the personalists see that the crisis is both material and spiritual, which is a crisis of building and a crisis of building a person (39).The second requirement: Personality and its relationship to existentialism: a philosophical current emerged in the twentieth century, calling for the importance and value of the existence of the human individual as it can be said: That existentialism was a response to the disadvantages of the First World War, which left thousands of dead and wounded, which made my thinkers that The era is searching for an idea or stream that restores the value to man and enhances the importance of his existence, so they spread their ideas through theater, literature and poetry until it became one of the most famous humanistic philosophical currents in Europe (Peter Kunzmann, Atlas of Philosophy ).

The Danish Surin Kierkegaard (1813-1855) is the spiritual father of existentialism and the founder of existentialism by attacking some ideas of the philosophers of his time, from those who underestimated the individual value as a philosophy (Hegel) according to his opinion, as the French (John Paul Sartre) is one of the most famous existential philosophers as his work as a soldier contributed A Frenchman against the Germans drew his attention to the importance of having thought that directs human attention and attention to the value of existence, as well as other thinkers such as the French (Gabriel Marcel) and the German (Karl Jasper) who left his mark and made a great impact on existential thought (42).(

Existentialism is divided into two parts (Azizu Mohamed, The Personality of Emmanuel eligious existentialism (Christianity), and one of its most famous pioneers (Gabriel Marcel) who dominated his existentialist thought of optimism and believed faith in the Lord to be able to solve human problems, as (Carl Jasper) had its effect on secular existentialism as He considered freedom to be a condition for reaching the Lord, and atheist existentialism, and one of its most famous thinkers (Sartre), who denied the existence of God as he considered him incapable of solving human problems, considering man as the creator of himself (person in philosophy www.zahya.over-blog.com).

\subsection{The most important intellectual principles advocated by existentialism}

They absolutely believe in human existence and take it as a starting point for all ideas and believe that man is the oldest thing in existence and what preceded him was nihilism, and that the existence of man is prior to what he is, and they say: they work to restore the total consideration of the human being and take into account his personal thinking, freedom, instincts, and feelings.

Existentialists believe in the absolute freedom of man, and that he has to establish his presence as he wishes and in any way he wants, without restricting him anything, and that a person must present the past and deny all restrictions, whether religious, social, philosophical or logical, and believers remind them: that religion is the subject of conscience As for life, including it, it is driven by the person's absolute will (Quoted from: Amari Sarah, Personality in Contemporary ).

Sanctification of freedom, because without freedom, existence loses its true meaning.

Protecting human desire to enjoy existence, eliminating feelings of disappointment and anxiety in this world and continuing life, and encouraging a feeling of happiness and enjoying the opportunity to possess life and 
freedom to achieve it (Ibrahim Khalil Al-Allaf, Rainier Habashi and the Personal Movement in Arab Philosophical Thought ).

Harnessing all energies and capabilities in the interest of achieving the individual self without giving importance to the essentials, matters, colleges or society.

Despite the agreement between personality and existentialism that the human being is the axis of thinking and highlighting the value of individual existence and the saying of freedom and the actors, it is any - personal it could not fully accept it because personality does not encourage man to leave his reality and neglect his present life in the hope of obtaining a better life after death, Personality also attacked the absurd and involuntary consequences of atheistic existentialism that go beyond the existence of man, his destiny, freedom, and his location from life, death, others, time, and place

Personality also differed from existentialism in the subject of freedom, as for personality, freedom has no boundaries, it is far beyond If you find in time or place that it is rather a call, a meeting and a transformation as (Monet) sees: it is a universal cosmic energy, but for existentialists they are divided into two streams (Bernard Delvaggio, translation: ): the Christian current, freedom has a close relationship with the fate of the human person, and the atheistic current is considered Freedom is like a prison, especially (Sartre) who considered the freedom of others as if it threatens his freedom and denies its self-existence (Jean-Paul Sartre, Existence and Nothingness ). Moreover, personality, unlike Sartre's existentialism, which considers the other (hell) sees in (the other) a need for (the person) on his way towards achieving The same, since personality goes into consideration that the process of realizing the same (the person) can only be done through For (the other) and interacting with him is based on the concept of the Trinity, which depicts God as a supreme being as three persons (father, son, and Holy Spirit) dialogue with his absolute love and not an isolated being, thus the other becomes the necessary path to reach and achieve the self (John, Oide, Hand, Existential Philosophy and Its Pioneers, 06/25/2009: www.ankawa.com ))

\section{3..5.Personality in the thought of Emmanuel Monnet}

(Monet) is one of the most famous founders and pioneers of personality, and its representatives in France, and during his life he worked to spread the principles of personality through his lessons and writings, then he published (1932) magazine (Fikr) which was the official spokesman for personality in France, and personality appeared in the midst of events The Great during the First and Second World Wars, and in light of this conflict between individualism and totalitarianism, which was an attempt to defend the human being, his dignity and values ( Amin Elias, Can Personal Philosophy represent a solution needed for today's world, on 2/23/2017: https://newspaper.annahar.com ).

Although this word was closely associated with (Monet), but it was not an innovation, it was found before him by some thinkers and intellectual trends in his era, as it is mentioned that it is of modern use, as he used it in France (Charles Ronovier) as the title of one of his books to express his concept of the person, And he used it in Germany (Max Schiller 1928-1874) against individualism to denote moral value For a person, as it was popularized in the United States of America and indicated in the works of (Royce) the loyalty and sincerity of a cause, and despite all this, she did not receive care and attention as what she received at (Monet), and so the persona had existed before (Monet) but was linked to it and took Its reputation is by its intellectual products and contributions (Amanouille Monet, Representative of Personality in France, 05/30/2018: www.ph:lomaghreb.com ).

This trend believes that the contemporary city is on the brink of collapse and is living a real crisis that it is heading towards collapse and pushing it towards a humanitarian catastrophe. The reason for this is its spiritual, moral, and economic greed bankruptcy to the extent that man becomes treated like a machine agent and is valued by what he produces of goods and what he receives of money, in order to confront this. (Monier) is trying to present a new vision based on Amanoil Monier, The Personality, translation: (Mahmoud Jamoul),

Rebuilding a new humanism that is able to integrate into a new civilization and the axis of this trend: it is the person and this is by renewing the values and morals of the contemporary man and the principles of his civilization according to spiritual foundations that raise the dignity of the human person and respect his relationships with others and transcend injustice, economic corruption and social discrimination.

Seek to understand the history of man as a free, intelligent, creative, creator of his history, and the basis for that is the person.

(Monet )believes that the global crisis of 1929 that threatened the well-being of European people and sounded the alarms of the danger of poverty in other countries of the world, prompted many philosophers to search for the causes of that crisis, and there were multiple interpretations. . But some young people - here the personalities - went on to say: that the cause of the crisis is both economic and moral, and that medicine cannot avoid neither the economic revolution nor the spiritual revolution (How did contemporary philosophy express human concern for existence, and what it called for its transcendence, on 12/5/2016: www.ouarsenis.com ), and this is what prompted the young personalities and (Monet) to search for an explanation of what they have 
become European civilization, most of their explanations were provided on the pages of the magazine (Fikr), and it was the first editorial of that magazine entitled: (Let's do a renaissance again).

The vision that Monnet seeks is based on two principles: they must move away from the Marxist interpretation that linked the causes of the crisis In economic conditions, and to overcome this crisis, economic reform is necessary, and we also move away from it To interpret the ideal that linked it to a valuable crisis and to overcome that is a moral reform, and then (Monnet's) vision to overcome the crisis is twofold, first we must reconsider the economic structures, and secondly we must review our ethical system so that we can reform the conditions of those exhausted societies

(Monier) defines a person as: (a spiritual being who contributes himself to his existence and the independence of his formation, and maintains this existence by believing in a series of values that he freely adopted and assimilated) (Ahmed Baji, The Personality of the Human Concept in Contemporary ), and (Monier) adds two attributes to the person which are rebellion and defection, because these two attributes confirm Distinguishing it from others, rejecting what is prevalent, and inviting it to establish a new society, as it includes the meaning of transcendence and moving forward, while continuing means to remain in the stage of slavery and also means the repetition of behaviors and actions that restrict a person's freedom and deprive him of his own actions and convictions, but this defection remains temporary and after That the individual is involved in the group

Through the foregoing, we find that (Monet) declares his rejection of isolation and isolation from the self, but a dialectical relationship must be established between the subject and the subject, between the interior and the outside as the person remains in a state of permanent conflict between his inner life and external objective things, especially since the personalization process is a movement Continuing to be free from all internal or external slavery within the framework of combining what is subjective with what is objective. (Monet) has emphasized this dialectical relationship between the subject and the subject, ie between the individual and society (between the ego and the other), especially since he rejected the individualistic and absolute selftendency that leads In the end to isolation and seclusion (The first part, the person, on 3/3/2016: www.edorous.com ).

The idea of personality (Monet) is based on a merger between what is spiritual with what is material and giving precedence to what is spiritual, but this idea does not uphold it unless it is linked to the idea of communication between people on the basis of love and sincerity. For her to have a collective life except through the continuity of her individuals so that he draws closer between them and they integrate and sympathize with each other and so the world that Monet seeks through his philosophy is: a specific world based on the idea of communication between its individuals in which the person opens to others and determines its characteristics His identity is that he is (we and the others) this on the one hand and on the other hand The real enemy of Monet's personality is the individualism that was an inevitable consequence of the French Revolution in 1789, as it on the one hand isolated man from his social milieu, and on the other hand represented the ideology adopted by the dominant class over others in Western societies.

Individualism produced a human being without controls characterized by freedom similar to anarchy, as he is not socially or morally framed, as he represents "the abstract man who has no ties and no natural determinants of his own, as man turns into a ruling family in the midst of freedom without direction and without borders" (Hassan Kahlawi, Individualism in Contemporary Philosophical Thought), As individualism has led the industrial societies to lose the idea of communication, on the basis of which people converge They coalesce with each other, so society remains on the basis of brotherhood and cooperation, but instead indifference spread and increased hatred between people and absent from these societies ways of fellowship, friendship and love, and this was a widespread failure of human brotherhood On it, and in order for the self to emerge from its isolation, its individuality, and the direction towards the person, Monet sets out a set of steps: (Murad Wahba, The Philosophical Lexicon )

Exodus: a person is an existence that can separate from itself and be at the disposal of others and cannot liberate others unless it liberates itself first of all.

The search for the truth: The individual should not search for the truth in the self-locked self, but rather the other ones, because the truth appears through contact with others and not through isolation. The truth is gained from experience and communication with others.

Take responsibility: the individual should take upon himself the fate of others with their pain and joys and bear responsibility for all of that.

Consistent with this, (Monier) believes that the state is a means to serve the person and society of persons and that their presence is linked to its function in ensuring mechanisms that help them in achieving their own and facilitate their efforts, as it is from this perspective that it opposes the trends that nullify the person in the interest of the state and its administrative apparatus, as well as what the anarchists who went to They call for the abolition of the state in the interest of the individual, in addition to that he opposed the position of those who see the need for force majeure to achieve the supremacy of social law and opposed the Marxist position that supports 
the priority of the class and the party over the individual so he (Monet) addressed the issue of the state in the context of his view of the concept of authority From an angle Legitimacy of the exercise of power by one party over another, therefore some mechanisms suggest:

That the person be protected against abuse of power, through the presence of a popular institution.

The subjection of the person is determined by his authority over himself, after which he is free.

Power is based on law, not on the strength of the majority.

The existence of power is associated with educational and political action.

The priority of authority is the priority of the person, and it is limited to care, protection and framing under the roof of the law, and thus (Monet) stands against (statist), that is, the authoritarian power of the state is amplified and he does not see the possibility of its intervention except where the person's existence is threatened, and within this perception the state takes A decentralized and pluralistic nature in a manner that achieves freedom and independence for its constituent groups and preserves their capacity for initiative, activity and communication (Ibrahim Madkour, The Philosophical Lexicon, )

Through the foregoing, we conclude that personality depicts human life as presence and commitment and not isolation and contempt for the self, that it is an openness to the other, that it is a living presence in the general human world, as well as that personality is to find meaning for the (person's) material needs and recognition of being a body, At the same time, it is a recognition of the transcendence of this (person) over the (individual) and over (the matter), for the person is the only one who preserves the human being his living reality i.e. his materialistic dimension, and his directed reality i.e. his spiritual dimension, opening up to others does not include abolishing the self and distinguishing it but rather means asserting the self It centered on itself first, then its exit into the world in order to practice its activity Efficiency without losing her personality

\section{Conclusion}

One of the most important intellectual currents that appeared in France during the thirties of the twentieth century in addition to existentialism and phenomenology. Personality is based on an ethical principle based on its content, respect for the human person and its absolute value. It rises above the world of political and economic institutions that are nothing but methods in the service of the person.

Emmanuel Meniere's one of the most prominent pioneers who presented a vision of the person based on the merging of what is spiritual with what is material in the human being while giving precedence to what is spiritual, stressing that personality is based on communication and human relations, because the person does not perceive himself except with others And highlighting the priority of the self over the subject and the self-existence over the total perception, personality sought to present itself as a solution to the human crisis that appears economic and spiritual depth cultural or as an alternative to the worsening crisis multidimensional in Europe and others

\section{References}

Deats, P.; Robb, C. (1986). The Boston Personalist Tradition in Philosophy, Social Ethics, and Theology. Mercer University Press. ISBN 978-0-86554-177-1

John English (2006-10-06). Citizen of the World. Knopf Canada. p. 147

Lawler, R. D. (1982). The Christian Personalism of Pope John Paul II (Vol. 1). Franciscan Pr

Crosby, John (2003). Personalist Papers. Washington, D.C.: Catholic University of America Press. p. 280

F. D. E. Schleiermacher Über die Religion,(1799), Hrsg. v. Andreas Arndt. Meiner, Hamburg 2004

Miles, R. (2010). Georgia Harkness: The Remaking of a Liberal Theologian. Library of theological ethics. Westminster John Knox Press

Burrow, R. (1999). Personalism: a Critical Introduction. St. Louis, MO: Chalice Press

Deats, P.; Robb, C. (1986). The Boston Personalist Tradition in Philosophy, Social Ethics, and Theology. Mercer University Press. ISBN 978-0-86554-177-1

John English (2006-10-06). Citizen of the World. Knopf Canada. p. 147

Lawler, R. D. (1982). The Christian Personalism of Pope John Paul II (Vol. 1). Franciscan Pr

Crosby, John (2003). Personalist Papers. Washington, D.C.: Catholic University of America Press. p. 280

F. D. E. Schleiermacher Über die Religion,(1799), Hrsg. v. Andreas Arndt. Meiner, Hamburg 2004

Miles, R. (2010). Georgia Harkness: The Remaking of a Liberal Theologian. Library of theological ethics. Westminster John Knox Press

Burrow, R. (1999). Personalism: a Critical Introduction. St. Louis, MO: Chalice Press

Deweer, D. (2013). The political theory of personalism: Maritain and Mounier on personhood and citizenship. International Journal of Philosophy and Theology. Routledge. Recuperado de https://lirias.kuleuven.be/bitstream/123456789/411862/1/IJP\%26T+gepubliceerd.pdf.

Balthasar, Hans Urs von, 1986, “On the Concept of Person," trans. Peter Verhalen, Communio: International Catholic Review, 13 (Spring): 18-26. 
Beabout, Gregory R., Ricardo F. Crespo, Stephen J. Grabill, Kim Paffenroth, and Kyle Swann, 2001, Beyond Self-Interest: A Personalist Approach to Human Action, Lanham, MD: Lexington Books.

Bengtsson, Jan Olof, 2006, The Worldview of Personalism: Origins and Early Development, Oxford: Oxford University Press

Bowne, Borden Parker, 1908, Personalism, Boston: Houghton Mifflin Company.

Brightman Edgar S., 1932, Is God a Person?, New York: Association Press .1952 ,Persons and Values, Boston: Boston University Press.

Brightman, Edgar S. (ed.), 1943. Personalism in Theology: A Symposium in Honor of Albert Cornelius Knudson, Boston: Boston University Press. .

Flewelling, Ralph Tyler and Rudolf Eucken, 1915, Personalism and the Problems of Philosophy: An Appreciation of the Work of Borden Parker Bowne, New York/Cincinnati: The Methodist Book Concern.

Hart, James G., 1992, The Person and the Common Life: Studies in a Husserlian Social Ethics, New York: Springer.

Knudson, Albert Cornelius, 1927, The Philosophy of Personalism. New York: The Abingdon Press.

Kohák, Erazim, 1984, The Embers and the Stars. A Philosophical Inquiry into the Moral Sense of Nature, Chicago: The University of Chicago Press.

Marcel, Gabriel, 1963, The Existential Background of Human Dignity, Cambridge, MA: Harvard University Press.

Maritain, Jacques, 1947, La personne et le bien commun (The Person and the Common Good), John J. Fitzgerald (trans.), Notre Dame, IN: University of Notre Dame Press, 1985.

Ibn Manzoor, Lisan Al-Arab, vol. 1, 3rd floor, Dar Al-Turath Al-Arabi, Beirut, 1988, p. 51.

Definition and meaning of personality in glossary of meanings, on 7/2/2018: www.aimaany.com/ar/dirct/ar-ar

Ibrahim Madkour, The Philosophical Lexicon, The General Authority for Emiri Press Affairs, Cairo, 1983, p. 101.

Personality, 06/30/2018: https://mawdoo3.com .

Hassan Kahlawi, Individualism in Contemporary Philosophical Thought, Madbouly Library, Cairo, 2004, p. 19, as well: Muhammad Jawad Mughniyah, Philosophical Doctrines and Terminology Dictionary, Dar Al-Hilal, Lebanon, D.T., p. 213.

The tape Marwa and Sassi Iman, The Islamic Personality Theory of Muhammad Aziz Al-Hababi, a supplementary memo to obtain a master's degree, submitted to the Faculty of Humanities and Social Sciences / University of Kassadi Merbah - Ouargla, Algeria, 2017, p. 15.

Jamil Saliba, The Philosophical Dictionary, Lebanese Book House, Beirut, 1982, p. 141.

See: Abdul Ridha Al-Taan, Amer Hassan Fayad, Ali Abbas Murad, Introduction to Modern and Contemporary Western Political Thought, Part 2, University of Baghdad, D.T., p. 21.

Murad Wahba, The Philosophical Lexicon, 5th floor, Dar Al-Quba Modern, Cairo, 2007, p. 455.

Sally Mohsen Latif, The Art Philosophy of Schopenhauer and Nietzsche and Its Impact on Some Postmodern Philosophers, House of Rule, Baghdad, 2011, p. 174.

André Laland, Laland's Philosophical Encyclopedia, translation: (Khalil Ahmad Khalil), part 3, Owaydan, Beirut, 2006, p. 1350.

Walter Sties, The History of Greek Philosophy, translation: (Mujahid Abdel Moneim Mujahid), the House of Culture for Publishing and Distribution, Cairo, 1984, p. 90.

Looking: Ghanem Muhammad Salih, the old and mediating political thought, Dar Al-Kutub for Printing and Publishing, Baghdad, 2001, p. 60.

See: Pratrind Russell, Wisdom of the West: a historical presentation of Western philosophy in its social and political context, translation: (Fouad Zakaria), The World of Knowledge, Kuwait, 1983, p. 87.

Peter Kunzmann, Atlas of Philosophy, translation: (George Katturah), 2nd edition, The Eastern Library, Beirut, 2007 , p. 57.

Azizu Mohamed, The Personality of Emmanuel Monnet, in Contemporary French Philosophy: The Controversy of Expansion and Expansion, Banks Publications, Lebanon, 2015, p. 72.

Sorour Talbi, Man in the Light of Christianity, 25/5/2014: www.jilrc.com .

The person in philosophy, 10/2/2008: www.zahya.over-blog.com. See also: Rene Descartes, an essay on the curriculum, translation: (Mahmoud Muhammad Al-Khudairi), 2nd edition, Dar Al-Kateb Al-Arabi, Cairo, 1989, p. 83. 
The first part, the person, on 3/3/2016: www.edorous.com

Simple definition of Marxism, 06/25/2011: www.shoala-hamraa.yoo7.com .

Quoted from: Amari Sarah, Personality in Contemporary Arab Thought: Muhammad Aziz Al-Hababi as a model, a graduation note for a master's degree in general philosophy, submitted to the Faculty of Social Sciences and Human Sciences / Dr. Moulay El-Taher University, 2017, p. 24.

Ibrahim Khalil Al-Allaf, Rainier Habashi and the Personal Movement in Arab Philosophical Thought, PF 21/8/2018: https://pupit.alwatan voic.com .

Bernard Delvaggio, translation: (ND Smith), New York Publishing and Distribution, D.T., 2017, p. 181.

Ismail Abdel-Fattah Abdel-Kafi, The Encyclopedia of Political Terminology, p. 485, 12/7/2017: www.soqukaz.com.

Amira Taha, The Concept of Existentialism, on 1/9/2017: wwwmawdoo3.com .

Jean-Paul Sartre, Existence and Nothingness, translation: (Abdel Rahman Badawi), Dar Al-Adab, Beirut, 1966, pp. 77-18

Ghada Al-Shami, Existential Philosophy: Presentation of Doctrine and Criticism of Thought, 11/11/2014: wwwalukah.net

John, Oide, Hand, Existential Philosophy and Its Pioneers, 06/25/2009: www.ankawa.com .

Amin Elias, Can Personal Philosophy represent a solution needed for today's world, on 2/23/2017: https://newspaper.annahar.com.

Amanouille Monet, Representative of Personality in France, 05/30/2018: www.ph:lomaghreb.com .

How did contemporary philosophy express human concern for existence, and what it called for its transcendence, on 12/5/2016: www.ouarsenis.com.

Amanoil Monier, The Personality, translation: (Mahmoud Jamoul), Arab Publications, Beirut, 1979, p. 107.

Ahmed Baji, The Personality of the Human Concept in Contemporary Philosophical Thought, Al-Mudawna Magazine, Fifth Issue, College of Arts and Languages, University of Blida, Algeria, 2016, p. 173 